\title{
Paclobutrazol, Gibberellic Acid, and Rhizome Size Affect Growth and Flowering of Zantedeschia
}

\author{
Brian E. Corr ${ }^{1}$ and Richard E. Widmer ${ }^{2}$ \\ Department of Horticultural Science, University of Minnesota, St. Paul, \\ MN 55108
}

Additional index words. Araceae, calla lily, floriculture, flowering potted plants, plant
growth regulators, Zantedeschia elliottiana, Zantedeschia rehmannii

Abstract. Growth and flowering of Zantedeschia elliottiana W. Wats. and Z. rehmannii Engl. were studied. Rhizomes of both species were produced either in a glasshouse or outdoors in California. Plants grown from glasshouse-produced rhizomes flowered within 90 days only when a preplant rhizome soak of 500 ppm GA, was applied. Control plants of both species flowered when grown from field-produced rhizomes, but a GA preplant rhizome soak significantly increased the number of flowers (spathe and spadix) produced. Paclobutrazol, applied as a preplant rhizome soak or as a soil drench when shoots were 2 to $3 \mathrm{~cm}$ long, significantly limited plant height of Z. rehmannii from either source if not treated with GA,. Paclobutrazol and GA, treatments interacted significantly to affect height and number of flowers of $Z$. rehmannii grown from fieldproduced rhizomes. Treatment with $\mathrm{GA}_{3}$ overcame the dwarfing effect of paclobutrazol, while paclobutrazol treatment limited flower production. Z. rehmannii rhizomes $>6.5 \mathrm{~cm}$ in diameter produced more shoots and leaves than smaller rhizomes, regardless of $\mathrm{GA}_{3}$ treatment. Emergence, number of shoots, and number of leaves from $\mathrm{Z}$. elliottiana were not significantly affected by the rhizome size-GA $\mathrm{G}_{3}$ variable combination. Production of normal flowers was increased by GA treatment of all sizes of $\mathrm{Z}$. rehmannii rhizomes except the smallest, with the most flowers being produced by plants from the largest rhizomes. Production of deformed flowers was greatest from rhizomes treated with $500 \mathrm{ppm} \mathrm{GA}_{3}$, with no deformed flowers on control plants.

The calla lily (Zantedeschia spp.) is produced and marketed as a cut flower and a flowering potted plant for its attractive spathes, commonly referred to as flowers. Critical factors for Zantedeschia as a potted floricultural crop include flower number, plant height, and shoot and leaf number.

Maximal flower production from Zantedeschia elliottiana and Z. rehmannii was obtained by treatment with $500 \mathrm{ppm} \mathrm{GA}_{3}$ as a preplant rhizome soak (Corr and Widmer, 1987). Tjia (1987a) reported that $\mathrm{GA}_{3}$ treatment may increase the number of deformed flowers produced. Application of $\mathrm{GA}_{3}$ to Spathiphyllum induced flowering in plants that otherwise would not flower, but inflorescence distortions were noted on $\mathrm{GA}_{3}$ treated plants (Henny, 1981). Peduncles

\footnotetext{
Received for publication 14 Aug. 1989. Scientific Journal Series Paper no. 17,230, Minnesota Agricultural Experiment Station, Univ. of Minnesota, St. Paul, MN 55108. We thank Brown Bulb Co., Capitola, Calif., and the New Zealand Calla Producers Assn. for donating the rhizomes used in this study. Portions of this research were funded by the American Floral Endowment and the New Zealand Calla Producers Assn. The cost of publishing this paper was defrayed in part by the payment of page charges. Under postal regulations, this paper therefore must be hereby marked $a d$ vertisement solely to indicate this fact. 'Graduate Research Assistant. Current address: Univ. of Tennessee, Dept. of Ornamental Horticulture and Landscape Design, Knoxville, TN 37901.

${ }^{2}$ Professor Emeritus.
}

curved abnormally and spathes developed abnormally or had additional appendages on plants that received $\mathrm{GA}_{3}$ as a foliar spray at 250, 500, or $1000 \mathrm{ppm}$. Application of $\mathrm{GA}_{3}$ to Achimenes longiflora increased the number of deformed flowers without increasing the total number of flowers (Vlahos, 1985).

When Zantedeschia are grown as flowering potted plants, height control by application of a plant growth retardant may be necessary. Paclobutrazol effectively controlled height, but ancymidol did not in the concentrations tested (Tjia, 1987b).

Zantedeschia rhizomes are graded by diameter. We found no reports in the literature relating growth or flowering to rhizome size. In Colocasia, another genus of the Araceae, larger rhizomes emerge more quickly, produce taller plants with more shoots, and yield more than do smaller rhizomes (Lee et al., 1979). In the Liliaceae, control of flowering of Lilium longiflorum is partially determined by bulb size. Larger bulbs produce more leaves and flowers than smaller bulbs (Kohl, 1967).

The objectives of this study were to examine the effects and interactions of $\mathrm{GA}_{3}$ and paclobutrazol treatments and source and size of rhizomes on growth and flowering of Zantedeschia, and to use the results to better understand the control of flowering.

Glasshouse-produced rhizomes. Zante deschia elliottiana and $Z$. rehmannii rhizomes were harvested from plants grown at 20C minimum, then held for 8 weeks at 22 $\pm 2 \mathrm{C}$ until preplant treatments were applied.
Rhizomes were soaked for $10 \mathrm{~min}$ in deionized water, 500 ppm $\mathrm{GA}_{3}, 0.5 \%$ or $1.0 \%$ paclobutrazol, or a combination of $500 \mathrm{ppm}$ GA, and $0.5 \%$ or $1.0 \%$ paclobutrazol. The paclobutrazol concentrations were chosen on the basis of preliminary experiments that indicated that $0.5 \%$ and $1.0 \%$ solutions would result in an average uptake of 2 or $4 \mathrm{mg}$ of paclobutrazol per rhizome, respectively.

Rhizomes were planted the following day (10 Oct. 1986) in 15 -cm pots (1.15-liter) in a medium of 1 soil : 1 sand : 2 sphagnum peat (by volume). When shoots were 2 to 3 $\mathrm{cm}$ long, one-half of the rhizomes from the deionized water and the $\mathrm{GA}_{3}$ presoak treatments were treated with a soil drench of 4 $\mathrm{mg}$ paclobutrazol in $240 \mathrm{ml}$ water per pot as described by Tjia (1987b). Plants were grown in an unshaded glasshouse with ambient photoperiod $\left(45^{\circ} \mathrm{N}\right.$ latitude), at a minimum of 20C with a daytime increase of up to 7C. Growth data were taken at 90 days after planting. There were five replications per treatment, with data analyzed as a two-way $2 \times 4$ factorial analysis of variance, and mean separation by Tukey's HSD.

Field-produced rhizomes. Rhizomes of both species were harvested in late Nov. 1986 by a commercial California producer and stored at $\approx 8 \mathrm{C}$ until shipment on 4 Feb. 1987. Rhizomes were treated on arrival, stored overnight, then planted the following morning as described previously for glasshouse-grown rhizomes. There were five replications per treatment, with data analyzed as previously described.

To determine if rhizome size influences the response to $\mathrm{GA}_{3}$, additional rhizomes from California were graded by diameter $(<2.5$, 2.5 to $4.4,4.5$ to 6.5 , and $>6.5 \mathrm{~cm}$ ), soaked in $\mathrm{O}, 100$, or 500 ppm $\mathrm{GA}_{3}$ for $10 \mathrm{~min}$., planted on 15 Mar. 1987, and grown for 120 days as described above. Because of a shortage of large rhizomes, the $>6.5$-cm-diameter rhizomes were treated with only $\mathrm{O}$ and $500 \mathrm{ppm} \mathrm{GA}_{3}$. Previous research has shown $500 \mathrm{ppm}$ to be the optimal concentration for flower production for 6- to 7-cm-diameter rhizomes (Corr and Widmer, 1987). Data were taken at first flower and 90 days postplanting. Total flower production was recorded at 120 days after planting. Flowers were categorized as normal (no abnormality of the spathe) or deformed (spathe incomplete, partially open, or crinkled). There were five replications per treatment, with data analyzed as a one-way completely randomized design, and mean separation by Tukey's HSD.

Glasshouse-produced rhizomes. Z. rehmannii, but not $Z$. elliottiana, treated with paclobutrazol only were shorter than plants not treated with either paclobutrazol or $\mathrm{GA}_{3}$ (control) at 90 days after planting (Table 1). There was no significant effect of paclobutrazol on total number of flowers (Table 1), date of emergence, days from plant to first flower, date of first flower, peduncle length, spathe length, spathe width, number of leaves per rhizome, number of shoots per rhizome, or number of leaves per shoot for either species (data not presented). 


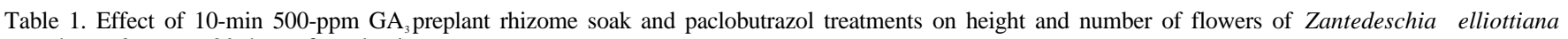
and $Z$. rehmannii 90 days after planting.

\begin{tabular}{|c|c|c|c|c|c|c|c|c|c|}
\hline \multirow{3}{*}{$\begin{array}{l}\text { Paclobutrazol }{ }^{2} \\
\text { (mg/rhizome) }\end{array}$} & \multicolumn{3}{|c|}{ Plant ht (cm) } & \multicolumn{2}{|c|}{ Flowers (no.) } & \multicolumn{2}{|c|}{ Plant ht $(\mathrm{cm})$} & \multicolumn{2}{|c|}{ Flowers (no.) } \\
\hline & \multicolumn{9}{|c|}{ Source of rhizomes } \\
\hline & Glasshouse & & Field & Glasshouse & Field & Glasshouse & Field & Glasshouse & Field \\
\hline & \multicolumn{5}{|c|}{ Z. elliottiana } & \multicolumn{4}{|c|}{ Z. rehmannii } \\
\hline No GA & & & & & & & & & \\
\hline 0 & 55.8 & & 38.3 & 0.0 & 2.5 & 59.2 & 39.8 & 0.8 & 4.0 \\
\hline 2 & 41.6 & & 26.0 & 0.0 & 1.0 & 40.8 & 25.4 & 0.0 & 2.6 \\
\hline 4 & 35.5 & & 23.6 & 0.0 & 1.2 & 33.3 & 25.2 & 0.0 & 1.5 \\
\hline 4 at emergence & 38.0 & & 29.2 & 0.0 & 2.0 & 38.8 & 32.2 & 0.0 & 3.2 \\
\hline \multicolumn{10}{|l|}{ GA soak } \\
\hline 0 & 45.0 & & 42.0 & 2.8 & 3.7 & 57.2 & 44.7 & 17.0 & 42.0 \\
\hline 2 & 41.2 & & 42.0 & 3.5 & 4.3 & 48.8 & 43.5 & 11.4 & 14.0 \\
\hline 4 & 48.0 & $\therefore$ & 41.0 & 3.3 & 2.0 & 54.0 & 43.2 & 12.6 & 10.7 \\
\hline 4 at emergence & 42.0 & & 42.0 & 3.8 & 5.0 & 54.6 & 39.2 & 21.6 & 20.6 \\
\hline \multicolumn{10}{|l|}{ Significance ${ }^{y}$} \\
\hline $\mathrm{GA}$ & NS & & $* * *$ & $* * *$ & $\mathbf{x}$ & $* * *$ & $* * *$ & $* * *$ & $* * *$ \\
\hline Paclobutrazol & NS & & NS & NS & $\mathbf{x}$ & $* *$ & $* * *$ & NS & $* * *$ \\
\hline Interaction & NS & & NS & NS & $\mathbf{x}$ & * & *** & NS & $* * *$ \\
\hline $\mathrm{HSD}_{0.05}$ & NS & & 16.3 & 2.7 & & 18.0 & 6.3 & 10.5 & 12.9 \\
\hline $\mathrm{HSD}_{0.01}$ & NS & & 19.9 & 3.2 & & 21.6 & 7.6 & 12.6 & 15.7 \\
\hline
\end{tabular}

${ }^{2}$ Paclobutrazol preplant rhizome soak or soil drench at shoot emergence.

yNs, ******, F test nonsignificant or significant at $P=0.05,0.01$, or 0.001 , respectively.

${ }^{x}$ Significance could not be calculated due to reduction of sample size by loss of plants to Erwinia soft rot.

Table 2. Effect of rhizome size and 10-min 100- or 500-ppm GA ${ }_{3}$ rhizome preplant soak on growth and flowering of Zantedeschia elliottiana and Z rehmannii.

\begin{tabular}{|c|c|c|c|c|c|c|c|c|c|c|}
\hline \multirow{2}{*}{$\begin{array}{l}\text { Rhizome } \\
\text { diam } \\
(\mathrm{cm})\end{array}$} & \multirow{2}{*}{$\begin{array}{c}\text { Rhizome } \\
\text { wt } \\
\text { (g) }\end{array}$} & \multirow{2}{*}{$\begin{array}{c}\mathrm{GA} \\
\text { concn } \\
(\mathrm{ppm})\end{array}$} & \multirow{2}{*}{$\begin{array}{c}\text { Time } \\
\text { to } \\
\text { emergence } \\
\text { (days). }\end{array}$} & \multicolumn{2}{|c|}{$\begin{array}{c}90 \text { days } \\
\text { post-plant }\end{array}$} & \multirow{2}{*}{$\begin{array}{c}\text { Days } \\
\text { to } \\
\text { first } \\
\text { flower }\end{array}$} & \multirow{2}{*}{$\begin{array}{l}\text { Ht } \\
\text { at first } \\
\text { flower } \\
(\mathrm{cm})\end{array}$} & \multirow{2}{*}{$\begin{array}{l}\text { Spathe } \\
\text { width } \\
\text { (cm) }\end{array}$} & \multirow{2}{*}{$\begin{array}{c}\text { Total } \\
\text { normal } \\
\text { flowers }\end{array}$} & \multirow{2}{*}{$\begin{array}{c}\text { Total } \\
\text { deformed } \\
\text { flowers }\end{array}$} \\
\hline & & & & $\begin{array}{l}\text { Shoots } \\
\text { (no.) }\end{array}$ & $\begin{array}{c}\text { Leaves } \\
\text { (no.) }\end{array}$ & & & & & \\
\hline \multicolumn{11}{|c|}{ Z. elliottiana } \\
\hline \multirow[t]{3}{*}{$<2.5$} & 15 & 0 & 13.2 & 5.2 & 14.5 & 70.3 & 40.7 & 5.0 & 1.0 & 0.0 \\
\hline & & 100 & 14.2 & 4.0 & 12.5 & 65.5 & 40.0 & 6.0 & 1.5 & 0.0 \\
\hline & & 500 & 12.2 & 4.7 & 12.0 & 63.5 & 48.0 & 5.0 & 2.3 & 0.3 \\
\hline \multirow[t]{3}{*}{$2.5-4.4$} & 30 & 0 & 12.6 & 4.7 & 13.7 & 64.7 & 42.0 & 6.3 & 2.3 & 0.0 \\
\hline & & 100 & 14.8 & 3.5 & 8.0 & 60.2 & 40.2 & 5.2 & 1.5 & 0.5 \\
\hline & & 500 & 14.0 & 2.5 & 8.0 & 62.0 & 39.2 & 5.5 & 3.0 & 0.0 \\
\hline \multirow[t]{3}{*}{$4.5-6.4$} & 53 & 0 & 12.0 & 5.0 & 11.0 & 56.0 & 49.8 & 7.2 & 1.2 & 0.0 \\
\hline & & 100 & 8.6 & 3.5 & 8.0 & 55.6 & 45.4 & 6.4 & 4.0 & 0.2 \\
\hline & & 500 & 10.8 & 5.3 & 9.7 & 55.5 & 46.5 & 5.8 & 3.2 & 0.0 \\
\hline \multirow[t]{3}{*}{$>6.5$} & 110 & 0 & 7.4 & 4.5 & 8.8 & 53.8 & 43.0 & 8.8 & 3.2 & 0.0 \\
\hline & & 100 & --- & --- & -.. & --- & $\ldots$ & --- & $\ldots$ & -.. \\
\hline & & 500 & 7.0 & 6.0 & 11.7 & 46.8 & 47.8 & 7.6 & 4.2 & 0.0 \\
\hline \multirow[t]{2}{*}{$\mathrm{HSD}_{0.05}$} & & & NS & NS & NS & 20.3 & NS & 2.8 & NS & NS \\
\hline & \multicolumn{10}{|c|}{ Z. rehmannii } \\
\hline \multirow[t]{3}{*}{$<2.5$} & -11 & 0 & 9.8 & 7.6 & 20.4 & 61.0 & 32.0 & 4.8 & 1.4 & 0.0 \\
\hline & & 100 & 11.8 & 7.6 & 25.6 & 64.4 & 37.2 & 4.0 & 5.0 & 0.2 \\
\hline & & 500 & 9.2 & 5.5 & 9.5 & 59.0 & 32.4 & 4.0 & 4.4 & 1.5 \\
\hline \multirow[t]{3}{*}{$2.5-4.4$} & 36 & 0 & 10.8 & 7.0 & 29.0 & 64.5 & 44.0 & 5.2 & 1.6 & 0.0 \\
\hline & - & 100 & 11.6 & 11.4 & 33.6 & 58.0 & 44.2 & 4.2 & 9.2 & 0.4 \\
\hline & . & 500 & 11.4 & 7.0 & 23.2 & 60.6 & 39.4 & 4.2 & 9.4 & 1.5 \\
\hline \multirow[t]{3}{*}{$4.5-6.4$} & 48 & 0 & 12.2 & 6.8 & 28.0 & 62.0 & 50.8 & 5.0 & 4.6 & 0.0 \\
\hline & & 100 & 10.8 & 7.4 & 26.6 & 57.2 & 45.2 & 4.2 & 10.8 & 0.2 \\
\hline & & 500 & 11.0 & 6.0 & 20.2 & 60.0 & 47.4 & 4.4 & 11.0 & 0.8 \\
\hline \multirow[t]{3}{*}{$>6.5$} & 130 & 0 & 5.6 & 15.0 & 45.4 & 47.2 & 47.0 & 3.8 & 9.4 & 0.0 \\
\hline & & 100 & $\cdots$ & --- & -.- & --- & $\ldots$ & ..- & ... & ... \\
\hline & & 500 & 6.6 & 17.6 & 49.4 & 45.4 & 48.4 & 4.4 & 27.8 & 0.6 \\
\hline $\mathrm{HSD}_{0.05}$ & & & 6.9 & 5.7 & 16.1 & 12.2 & 11.1 & NS & 5.7 & 1.3 \\
\hline $\mathrm{HSD}_{0.01}$ & & & 14.4 & 6.8 & 19.0 & 14.4 & 13.1 & NS & 6.8 & 1.6 \\
\hline
\end{tabular}

Treatment of rhizomes with $\mathrm{GA}_{3}$ overcame the limitation of plant height caused by paclobutrazol (Table 1). The most profound effect of $\mathrm{GA}_{3}$ treatment was the promotion of flowering of glasshouse-produced rhizomes. Plants grown from untreated glasshouse-produced rhizomes flowered sparsely or not at all during the 90-day growth period (Table 1). Gibberellic acid treatment of rhizomes of either species did not significantly affect date of emergence, number of leaves, number of shoots, or number of leaves per shoot (data not presented).

Field-produced rhizomes. In contrast to results with glasshouse-produced rhizomes, all plants grown from field-produced rhizomes flowered, with or without $\mathrm{GA}_{3}$ treatment, although $\mathrm{GA}_{3}$ treatment increased flower production (Table 1). All other results were similar to those obtained with glasshouse-produced rhizomes. Paclobutrazol treatment significantly interacted with $\mathrm{GA}_{3}$ treatment for $Z$. rehmannii (Table 1). Because of losses of $Z$. elliottiana to bacterial soft rot (Erwinia sp. ), multiple comparison statistics could not be calculated for number of flowers produced for that species. Z. rehmannii produced significantly more flowers when treated with $\mathrm{GA}_{3}$, while paclobutrazol treatment significantly limited the number of flowers produced. Paclobutrazol also interacted with $\mathrm{GA}_{3}$ treatment (Table 1).

Rhizome size and gibberellin. Days to first 
flower tended to be fewer with larger Z. elliottiarra rhizomes, although significantly so only when comparing untreated rhizomes $<2.5 \mathrm{~cm}$ to $\mathrm{GA}_{3}$-treated rhizomes $>6.5 \mathrm{~cm}$ (Table 2). Z. elliottiana spathe width was greatest on plants grown from untreated rhizomes $>6.5 \mathrm{~cm}$ and significantly smaller on plants grown from rhizomes $<2.5 \mathrm{~cm}$, regardless of $\mathrm{GA}_{3}$ treatment (Table 2). Days to emergence, shoot and leaf number, height at first flower, and number of flowers from Z. elliottiana rhizomes were not significantly affected by rhizome size-GA treatment $_{3}$ combinations (Table 2).

Shoots tended to emerge more quickly and have more shoots and leaves from Z. rehmannii rhizomes $>6.5 \mathrm{~cm}$ than from smaller rhizomes, regardless of $\mathrm{GA}_{3}$ treatment $(\mathrm{Ta}-$ ble 2). Plants grown from rhizomes $>6.5 \mathrm{~cm}$ flowered the most quickly, regardless of $\mathrm{GA}_{3}$ treatment (Table 2). The shortest Z. rehmannii plants at first flower were grown from rhizomes $<2.5 \mathrm{~cm}$ in diameter (Table 2 ). Production of normal flowers was increased by $\mathrm{GA}_{3}$ treatment of $Z$. rehmannii rhizomes of all sizes except the smallest, with the most flowers produced from the largest rhizomes (Table 2). Production of deformed flowers was greatest from rhizomes treated with 500 ppm $\mathrm{GA}_{3}$ less from rhizomes treated with $100 \mathrm{ppm}$, and none from untreated rhizomes (Table 2). At 500 pm GA 3 more deformed flowers were produced from smaller than from larger Z. rehmannii rhizomes, although the difference was not significant (Table 2). Spathe width of $Z$. rehmannii was not significantly affected by the rhizome size-GA treatment combination (Table 2).

Our results confirm previous research (Tjia, $1987 b$ ) indicating that paclobutrazol provides effective height control on $Z$. rehmannii and Z. elliottiana. Paclobutrazol applied as a preplant rhizome soak was of equal or greater effectiveness than the-commercially recommended post-emergence drench for height control of Zantedeschia, but it decreased flower production from field-produced Z. rehmannii rhizomes (Table 1) by $>60 \%$. The preplant soak maybe more costeffective, however, since the cost of labor and plant growth regulator used likely would be lower.

Gibberellin treatment overcame an unknown block to flowering in plants grown from glasshouse-produced rhizomes. Presumably, an environmental requirement was missing during the growth or storage of these plants, since none of the untreated plants produced flowers in the quantity expected. According to preliminary research, length of storage of Zantedeschia rhizomes can influence days to flower and number of flowers produced per rhizome (Corr, 1988). Glasshouse-produced rhizomes were stored for 8 weeks, which is sufficiently long to cause rapid vegetative growth (Corr and Widmer, 1988), but may not have been long enough to cause flowering within 90 days of planting. We have noted no effect of rhizome storage temperature on subsequent flowering (Corr and Widmer, unpublished). Therefore, it is unlikely the difference in flowering be- tween glasshouse- and field-produced rhizomes can be explained simply by storage temperature difference.

Since all tested rhizome sizes flowered, smaller sizes, which are less expensive, may be useful for commercial production. Several smaller rhizomes planted in a single pot may be more profitable than a single larger rhizome for flowering potted-plant production. The cost per flower produced, rather than cost per rhizome, needs to be considered.

The increased production of misshapen flowers as a result of $\mathrm{GA}_{3}$ treatment agrees with previous work (Tjia, 1987a). The large increase in total flower production outweighs the relatively small increase in deformed flowers. The increase in deformed flowers was similar to the response of Achimenes to $\mathrm{GA}_{3}$, although in Achimenes the number of normal flowers was unchanged with $\mathrm{GA}_{3}$ application (Vlahos, 1985).

The results of these experiments are compatible with other data (Corr, 1988) that show that flower initiation of $\mathrm{GA}_{3}$-treated rhizomes occurs at the time of planting and continues for $\approx 4$ to 6 days after planting. Paclobutrazol rhizome presoak appears to inhibit the initiation that occurs after planting. Paclobutrazol applied as a soil drench, $\approx 4$ weeks after planting, had a lesser effect on , flower production. Commercial producers of Zantedeschia as flowering potted plants may wish to consider the use of $\mathrm{GA}_{3}$ in combi- nation with paclobutrazol to produce plants with an aesthetically pleasing shape and adequate flower production.

\section{Literature Cited}

Corr, B.E. 1988. Factors influencing growth and flowering of Zantedeschia elliottiana and Z. rehmannii. .PhD Diss., Univ. of Minnesota, St. Paul.

Corr, B.E. and R.E. Widmer. 1987. Gibberellic acid increases flower number in Zantedeschia elliottiana and Z. rehmannii. HortScience 22:605-607.

Corr, B.E. and R.E. Widmer. 1988. The effect of rhizome storage on growth of Zantedeschia elliottiana and Z. rehmannii. HortScience 23:1001-1002.

Henny, R.J. 1981. Promotion of flowering in Spathiphyllum 'Mauna Loa' with gibberellic acid. HortScience 16:554-555.

Kohl, H.C. 1967. Correlation between rate of leaf initiation and apex diameter of Lilium longiflorum cv. Ace. HortScience 2:15-16.

Lee, M.S., J.H. Lee, and S.O. Yu. 1979. Effect of seed tuber age and weight on major characters in different local strains of tare, Colocasia antiquorum (Schott)(in Korean with English summary). J. Korean Soc. Hort. Sci. 20:134141.

Tjia, B. 1987a. The acid test. Greenhouse Manager 5:128-134.

Tjia, B. 1987b. Growth regulator effect on growth and flowering of Zantedeschia rehmannii hyb. HortScience 22:507-508.

Vlahos, J.C. 1985. Effects of GA and BA on two cultivars of Achimenes longiflora under two levels of irradiance. Acta Hort. 167:225-235. 